\title{
PERTUMBUHAN DAN PRODUKSI BAWANG MERAH (ALLIUM CEPA L) DENGAN PEMBERIAN MIKROORGANIME LOKAL (MOL) FESES WALET PADA MEDIA GAMBUT
}

\author{
Amelia Nanda ${ }^{1}$, Intan Sari², Elfi Yenny Yusuf ${ }^{2}$ \\ ${ }^{1}$ Jurusan Agroteknologi, Fakultas Pertanian, Universitas Islam Indragiri, Tembilahan \\ Email: 20ameliananda@gmail.com
}

\begin{abstract}
Research on the effect of local microorganism concentration (MOL) of swallow faeces on the growth of shallots (Allium cepa L) on peat media has been carried out at the experimental garden of the Islamic University of Indragiri UNISI, Indragiri Hilir Regency, Riau Province for 3 months from January to March 2020. The aim of this studyto knoweffect of local microorganism concentration (MOL) of swallow faeces on the growth of shallot (Allium cepa $L$ ) on peat media. This study used a non-factorial completely randomized design (CRD) consisting of 6 treatments with 3 replications which consists of $0 \%, 5 \%, 10 \%, 15 \%, 20 \%$, $25 \%$. Parameters observed in this study were plant height, number of tubers per clump, wet weight of tubers per clump, dry weight of tubers per clump, tuber weight per clump. Observational data were analyzed by means of variance (ANNOVA) and continued with the Tukey HSD further test with a level of $5 \%$. The results showed that pbehavior $25 \%$ was able to increase the parameters, namely plant height, wet weight of tubers per clump, dry weight of tubers per cluster, dry weight of tubers, and fruit worth selling, except for the treatment of the number of tubers per clump;
\end{abstract}

Keywords: Shallots, MOL, wallet feces, peat soil

\begin{abstract}
Abstrak
Penelitian pengaruh konsentrasi mikroorganisme lokal (MOL) feses walet terhadap pertumbuhan bawang merah (Allium cepa L) pada media gambut telah dilaksanakan di Kebun percobaan Universitas Islam Indragiri UNISI Kabupaten Indragiri Hilir Propinsi Riau selama 3 bulan dari bulan Janurai sampai Maret Tahun 2020. Penelitian ini bertujuan untuk mengetahui pengaruh konsentrasi mikroorganisme lokal (MOL) feses walet terhadap pertumbuhan bawang merah (Allium cepa $\mathrm{L}$ ) pada media gambut Penelitian ini menggunakan rancangan acak lengkap (RAL) non factorial yang terdiri dari 6 perlakuan dengan 3 kali ulangan yaitu terdiri dari $0 \%, 5 \%, 10 \%, 15 \%, 20 \%, 25 \%$ Parameter pengamatan pada penelitian ini yaitu, tinggi tanaman, jumlah umbi per rumpun, berat basah umbi per rumpun, berat kering umbi per rumpun, bobot umbi per rumpun. Data pengamatan dianalisis dengan sidik ragam (ANNOVA) dan dilanjutkan dengan uji lanjut tukey HSD dengan taraf $5 \%$ Hasil penelitian menunjukkan bahwa perlakuan $25 \%$ mampu meningkatkan parameter yaitu Tinggi tanaman, Berat basah umbi per rumpun, Berat kering umbi perrumpun, bobot kering umbi, dan buah layak jual, kecuali pada perlakuan jumlah umbi perrumpun;
\end{abstract}

Kata kunci: Bawang merah, MOL, feses wallet, tanah gambut

\section{PENDAHULUAN}

Bawang merah (Allium cepa L.) merupakan salah satu komoditi sayuran unggulan yang telah lama diusahakan penananamnya oleh petani secara intensif. sayuran ini termasuk ke dalam kelompok rempah yang sering digunakan sebagai bumbu penyedap makanan serta obat tradisional. Manfaat bawang merah yang begitu besar dan dekat dengan masyarakat menjadikan bawang merah memiliki nilai 
ekonomi yang tinggi, prospek pasar yang luas dan kebutuhannya di masa mendatang akan terus meningkat sehingga harus diiringi dengan peningkatan produksi.

Menurut hasil proyeksi yang dilakukan tahun 2015-2019, produksi bawang merah akan terus mengalami peningkatan hingga mencapai 1,31 juta ton pada tahun 2019 dengan rata-rata pertumbuhan $1,24 \%$ per tahun. Sementara konsumsi nasional bawang merah juga diproyeksikan akan meningkat dengan bertambahnya jumlah penduduk dengan rata-rata pertumbuhannya $1,73 \%$ per tahun (Kementan, 2015). Produksi bawang merah baik secara nasional maupun regional khususnya di Riau tergolong masih rendah, produksi bawang merah di Riau hanya menghasilkan produksi sekitar 10 hingga 12 ton/ha (BPS Provinsi Riau, 2012), berbanding dengan daerah Jawa Timur hasil produksi bawang merah mencapai 37 hingga 41 ton/Ha (BPS provins jawa timur 2018).

Rendahnya produksi bawang merah di Riau disebabkan beberapa faktor, yaitu kurangnya pengetahuan tentang pemberian pupuk dasar (amelioran), kurangnya pemahaman tentang varietas yang digunakan serta beralih fungsinya lahan, seperti lahan hortikultura yang beralih fungsi menjadi lahan perkebunan Sehingga lahan untuk menanam jenis tanaman hortikultura kurang tersedia, lahan yang masih tersedia luas di Riau adalah jenis lahan gambut. Kabupaten Indragiri Hilir memiliki potensi lahan gambut yang cukup luas tetapi belum termamfaatkan dengan maksimal.

Tanah gambut gambut merupakan jenis tanah yang paling dominan di kabupaten Indragiri hilir yaitu mencapai $73,32 \%$ dari luas wilayahnya $(874,161,66$ ha) dan umumnya mempunyai ketebalan $>2 \mathrm{~m}$ dan $\mathrm{pH}$ berkisar 3,5-6. (LPPM Politeknik pertanian dan bappeda Kabupaten Indragiri Hilir 2006). Hal ini menggambarkan bahwa kabupaten indragiri hilir mempunyai potensi untuk budidaya bawang merah akan tetapi menurut Lubis et al,(1993), pemamfaatan tanah gambut sebagai lahan pertanian menghadapi berbagai kendala diantaranya sifat fisik dan kimia yang kurang mendukung untuk pertumbuhan tanaman.

Zubaidah et al.(2003) menyatakan kendala sifat kimia pada tanah gambut antara lain reaksi tanah sangat masam, Kapasitas Tukar Kation (KTK) sangat tinggi, kejenuhan bsa sangat rendah dan kandungan bahan organik dengan rasion $\mathrm{C} / \mathrm{N}$ yang tinggi. Kondisi ini sangat tidak mendukung keterrsediaan hara $\mathrm{P}, \mathrm{K}, \mathrm{Ca}$ dan $\mathrm{Mg}$ bagi tanaman dan menyebabkan pertmbuhan tanaman akan terhambat sehingga produksinya rendah.

Salah satu unsur penunjang keberhasilan budidaya bawang merah di tanah gambut adalah pemenuhan unsur hara dan perbaikan bahan organik yang terkandung didalam media tanam atau tanah. Perbaikan bahan organik tanah bisa dilakukan dengan pemberian pupuk organik baik dalam bentuk cair maupun padat. Menurut Widiana (2007) pemberian pupuk organik memiliki kelebihan diantaranya menambah unsur hara dalam tanah memperbaiki sifat fisik, kimia dan biologi tanah serta menekan residu sehingga tidak menimbulkan dampak negatif terhadap lingkungan.

Pupuk organik sudah cukup terkenal dikalangan masyarakat Indonesia. Kebiasaan masyarakat yang lebih memilih pupuk anorganik, membuat keberadaan pupuk organik dikesampingkan karena, tata cara pembuatannya yang memakan waktu cukup lama, itulah yang membuat masyarakat lebih memilih pupuk anorganik. Padahal pembuatan pupuk organik tidak membutuhkan biaya yang besar, sehingga bisa menghemat pengeluaran, namun membutuhkan waktu pembuatan yang cukup lama 2 - 3 bulan. Pengolahan pupuk organik dapat dipercepat dengan penambahan MOL (mikroorganisme lokal), sehingga hanya butuh waktu 3 minggu dalam pembuatannya.

Mikroorganisme Lokal merupakan pupuk organik cair yang dibuat dari bahan organik yang berfungsi sebagai pupuk/biofertiliser yang memiliki kandungan unsur hara makro dan mikro, dan bakteri yang dapat merombak bahan organik sehingga dapat meningkatkan kualitas tanaman (Santosa, 2008). Pembuatan Mol berasal dari bahan bahan organik. Bahan organik yang mudah busuk membuat pembentukan Mol menjadi lebih cepat, karena dalam pembuatan Mol hal yang paling dibutuhkan adalah mikroorganisme yang ada di dalamnya, mikroorganiseme yang terdapat pada mol yaitu bakteri fotosintetik, lactobacillus sp, streptonosin, actinomicates, dan ragi (Gayam, 2016).

Menurut Hadinata (2008), Mol adalah mikroorganisme yang dimanfaatkan sebagai starter dalam pembuatan pupuk organik padat maupun cair. Bahan utama MOL terdiri dari beberapa komponen yaitu karbohidrat, glukosa, dan sumber mikroorganisme.Menurut Purwasamita dan Kurnia (2009), MOL mengandung unsur hara makro dan mikro dan juga mengandung mikroba yang berpotensi sebagai perombak bahan organik, perangsang perumbuhan, 
dan sebagai agen pengendali hama dan penyakit tanaman.

Penggunaan Mol juga dapat mengurangi pencemaran lingkungan karena limbah yang tidak termanfaatkan dapat bermanfaat. Selama ini kotoran burung walet belum maksimal dimanfaatkan oleh para penangkar burung walet. Biasanya rumah burung walet dibersihkan setiap bulan dari kotoran agar kesehatan burung terjaga serta mencegah hama dan penyakit, yang dapat menurunkan mutu sarang. Kotoran burung walet selama ini hanya di anggap sebagai limbah.

Kotoran burung walet merupakan limbah yang jarang di mamfaatkan oleh petani. Kotoran burung walet mengandung mengandung C-Organik 50.46\%, N/total $11.24 \%$, dan $\mathrm{C} / \mathrm{N}$ rasio 4.49 dengan $\mathrm{pH}$ 7.97, Fosfor $1.59 \%$, Kalium $2.17 \%$, Kalsium $0.30 \%$, Magnesium 0.01\%. (Laboratorium Kimia dan Kesuburan Tanah Fakultas Pertanian Untan). Melihat kandungan hara dan $\mathrm{Ph}$ kotoran burung walet di atas, maka dapat di katakan bahwa kotoran burung walet mempunyai potensi untuk di gunakan sebagai salah satu pupuk.

Firmansyah (2019) menyatakan bahwa berdasarkan hasil analisis kandungan hara dalam pupuk, pupuk kandang walet memiliki kandungan $\mathrm{C}$ organik, $\mathrm{N}$ total, dan kadar air yang jauh lebih tinggi di bandingkan pupuk kandang ayam dan pupuk kandang burung puyuh. Kandungan $\mathrm{C}$ organik pupuk kandang walet mencapai tiga kali lipat pupuk kandang ayam dan pupuk kandang puyuh, bahkan $\mathrm{N}$ totalnya mencapai 6 kali lipat dari kedua jenis pupuk kandang tersebut.

Hariyadi (2012) dalam penelitiannya menyatakan bahwa pertumbuhan cabai rawit di tanah gambut di pengaruhi oleh takaran pemberian guano. Pemberian 10 ton/ha guano walet dengan 1 (satu) kali pemberian di tanah gambut pedalaman kalimantan memperlihatkan pertumbuhan dan hasil yang nyata lebih tinggi di bandingkan perlakuan 5 ton/ha dan 20ton/ha namun tidak berbeda nyata dengan perlakuan 15 ton/ha. Pemberian 10 ton/ha guano walet menghasilkan 19,83 g bobot kering tanaman bobot buah sebanyak 03,30 g.

Berdasarkan uraian di atas, penulis tertarik untuk melakukan penelitian ini dengan menggunakan MOL Feses Walet. Maka penulis memilih judul "Pertumbuhan dan Produksi Bawang Merah (Allium cepa $L$ ) dengan Pemberian Mikroorganime Lokal (MOL) Feses Walet pada Media Gambut"

\section{TINJAUAN PUSTAKA}

\section{1.}

\section{Botani Bawang Merah}

\subsubsection{Klasifikasi}

Bawang merah merupakan salah satu dari sekian banyak jenis bawang yang ada di dunia. Bawang merah (Allium cepa L.) merupakan tanaman semusim yang membentuk rumpun dan tumbuh tegak dengan tinggi mencapai $15-40 \mathrm{~cm}$ (Rahayu, 1999). Menurut Tjitrosoepomo (2010), bawang merah dapat diklasifikasikan sebagai berikut:

Kingdom

Divisi

Kelas : Monocotyledonae

Ordo : Liliales

Famili : Liliaceae

Genus : Allium

Spesies : Allium cepa $L$.

\section{Morfologi tanaman bawang merah} 1. Akar

Akar tanaman bawang merah terdiri dari akar pokok (primary root) yang berfungsi sebagai tempat tumbuh akar adventif (adventitiouns root) dan bulu akar yang berfungsi untuk menopang berdirinya tanaman serta menyerap air dan zat-zat hara dari dalam tanah. Pada kedalaman antara 15-20 cm, jumlah perakaran tanaman bawang merah dapat mencapai 20 200 akar. Diameter bervariasi antara 5-2 mm. Akar cabang tumbuh dan terbentuk anatara 3-5 akar (AAK, 2004).

\section{Batang}

Tanaman bawang merah memiliki batang sejati atau disebut diskus yang berbentuk seperti cakram, tipis dan pendek sebagai tempat melekat perakaran dan akar tunas. Di bagian atas dickus terbentuk batang semu yang tersusun dari pelepah - pelepah daun. Di antara lapisan kelopak bulbus terdapat mata tunas yang dapat membentuk tanaman baru atau anakan, terutama pada spesies bawang merah (Rukmana,1994).

\section{3, Daun}

Menurut Sudirja (2007), daun bawang merah berbentuk silindris kecil memanjang antara 50-70 cm, berlubang dan bagian ujungnya runcing berwana hijau muda sampai tua, letak daun melekat pada tangkai yang ukurannya relatif pendek.

\section{Bunga}

Tangkai daun keluar dari ujung tanaman yang panjang antara $30-90 \mathrm{~cm}$, dan di ujungnya terdapat 50 - 200 jumlah kuntum bunga yang tersusun melingkar (bulat) seolah - olah berbentuk payung (Umbrella). 
Tiap kuntum bunga terdiri atas 5 - 6 helai daun bunga yang berwarna putih, 6 benang sari berwarna hijau atau kekuning kuningan, 1 putik dan bakal buah berbentuk hampir segitiga (Wibowo, 2009).

\section{Buah}

Buah berbentuk bulat, bagian pangkal umbi membentuk cakram dengan ujungnya tumpul membungkus biji berjumlah $2-3$ butir. Bentuk biji pipih, sewaktu masih muda berwarna bening atau putih, tetapi setelah tua menjadi hitam. Biji - biji berwarna merah dapat dipergunakan sebagai bahan perbanyakan tenaman secara generatif (Rukmana, 1995).

\section{Umbi Lapis}

Umbi lapis bawang merah sangat bervariasi. Bentuknya ada yang bulat, bundar sampai pipih, jika dipotong bahagian lapisan - lapisan umbi terlihat berbentuk cincin. Kelopak daun tipis dan mengering tetapi cukup liat. Kelopak yang menipis dan kering ini membungkus lapisan kelopak daun yang ada di dalamnya (yang juga saling membungkus) dan membengkak. Karena kelopak daunnya membengkak, bagian iniakan terlihat mengembung. sedangkan ukuran umbi meliputi besar sedang dan kecil. (Wibowo, 2006).

\subsection{Syarat Tumbuh Tanaman Bawang Merah}

\section{a. Iklim}

Daerah yang paling baik untuk budidaya bawang merah adalah daerah beriklim kering yang cerah dengan suhu udara $250 \mathrm{C}$ - 320 C. Daerah yang cukup mendapat sinar matahari juga sangat diutamakan, dan lebih baik jika lama penyinaran matahari lebih dari 12 jam (Wibowo, 2006). Bawang merah dapat tumbuh di dataran rendah sampai dataran tinggi pada ketinggian 0-1000 mdpl. Tetapi produksi terbaik dihasilkan dari dataran rendah pada ketinggian 0-400 mdpl yang didukung keadaan iklim meliputi suhu udara antara $25-30^{\circ} \mathrm{C}$ dan iklim kering, tempat terbuka dengan pencahayaan \pm 70 $\%$, karena bawang merah termasuk tanaman yang memerlukan sinar matahari cukup panjang, tiupan angin sepoi-sepoi berpengaruh baik bagi tanaman terhadap laju fotosintesis dan pembentukan umbinya akan tinggi (BPPT, 2007).

\section{b. Tanah}

Tanah yang baik untuk pertumbuhan tanaman bawang merah adalah tanah yang memiliki aerase dan drainase yang baik. Di samping itu hendaknya dipilih tanah yang subur dan banyak mengandung bahan organis atau humus. Jenis tanah yang paling baik adalah tanah lempung yang berpasir atau berdebu karena sifat tanah yang demikian ini mempunyai aerase dan draenase yang baik. Tanah yang demikian ini mempunyai perbandingan yang seimbang antara fraksi liat, pasir dan debu. Tanah yang paling baik untuk lahan bawang merah adalah tanah yang mempunyai keasaman sedikit agak asam sampai normal, yaitu $\mathrm{pH}$ nya antara $6,0-6,8$. Keasaman dengan $\mathrm{pH}$ antara 5,5 - 7,0 masih termasuk kisaran keasaman yang dapat digunakan untuk lahan bawang merah (Wibowo, 2007).

\subsection{Tanah \\ Gambut \\ dan}

\section{Permasalahannya}

Gambut adalah bahan organik yang tertimbun secara alami dalam keadaan anaerob sedangkan menurut (Prasetyo,1986 cit Hardjowigeno, 2003) tanah gambut adalah tanah yang lapisan bahan organik cukup tebal yang merupakan endapan bahan organik setempat terdiri dari sisa jaringan tumbuhan yang menumbuhi dataran rawa. Tanah gambut atau organik menurut taksonomi tanah termasuk golongan (ordo) Histosol (Setiadi, 1996).

Gambut terbentuk oleh lingkungan yang khas yaitu rawa atau suasana genangan yang terjadi hampir sepanjang tahun. Kondisi anaerob akibat keadaan hidro-topografi berupa gengangan, luapan akibat pasang surut atau keadaan yang selalu basah sehingga mencegah aktivitas mikroorganisme yang diperlukan dalam perombakan. Dengan kata lain pada kondisi ini laju penimbunan bahan organik lebih besar dari pada mineralisasi. Lajunya penimbunan gambut dipengaruhi oleh perpaduan antara keadaan topografi dan curah hujan yang tinggi serta didukung oleh sifat tanah dengan kandungan liat yang rendah (Noor, 2001).

Berdasarkan kesuburan tanah gambut dapat dibedakan atas gambut subur (eutropik) gambut sedang (mesotropik) dan gambut miskin (oligotropik). Berdasakan kondisi lingkungan akumulasinya gambut terdiri atas; gambut topogenous adalah gambut yang dibentuk pada depresi topografi dan diendapkan dari sisa tumbuhan yang hidupnya mengambil nutrisi tanah mineral dan air tanah sehingga gambut ini termasuk gambut eutropik yang kaya akan unsur hara, gambut ombrogenus adalah gambut yang terbentuk dalam lingkungan pengendapan dimana tumbuhan pembentuk semasa hidupnya hanya tumbuh dari air hujan gambut ini disebut sebagai gambut oligotropik atau gambut miskin akan unsur hara (Setiadi, 1996). 
Tingkat ketebalan gambut adalah parameter penting dalam mengkarakterisasi lahan gambut. Untuk tujuan pemetaan pusat penelitian tanah mengklasifikasikan gambut kedalam kelas ketebalan gambut, yakni dangkal ; <1,0 M, sedang ; 1,0-2,0 M, dalam ; 2,0-3,0 M, sangat dalam ; > 3,0 M (Setiadi 1996). PH tanah gambut sangat masam berkisar antara 3,5-5,0 dan kandungan C-organiknya $18-40 \%$ dari aspek ketersediaan unsur hara masalah utama adalah ketidak seimbangan hara dan tingginya kadar mangan besi dan sulfat ( Barcia, 2006 cit Ainun nita 2011).

Menurut Hardjowigeno

mengungkapkan tanah gambut sifatnya bermacam-macam tergantung dari jenis vegetasi yang menjadi tanah gambut tersebut. Tanah gambut yang terlalu tebal (lebih dari 2 meter) umumnya tidak subur karena vegetasi yang busuk menjadi tanah gambut tersebut terdiri vegetasi yang miskin unsur hara. Tanah gambut yang subur umumnya mempunyai ketebalan antara 40$100 \mathrm{~cm}$

Berdasarkan tingkat kematangannya tanah gambut dikelompokkan kedalam 3 kelas yaitu (1) fibrik. Merupakan gambut yang mentah memiliki kandungan serat yang tinggi(> 66\%) gambut sangat kasar, masih tampak dengan jelas bagian jaringan tanaman, warna air coklat gelap dan keruh, (2) Hemik. Yaitu gambut setengah matang memiliki kandungan serat kasar sedang (33$66 \%$ ) warna air coklat terang sampai agak gelap, (3) saprik. Merupakan gambut matang berkadar serat halus $(<33 \%)$ air berwarna coklat terang, tanah berwarna hitam dan bentuk jaringan tanaman tidak dapat diidentifikasi lagi (Barchia, 2006 cit Ainun nita, 2011).

Menurut Noor (2011), menyebutkan bahwa sifat dan ciri fisik tanah gambut antara lain tingkat ketebalan gambut, penurunan permukaan (subsidence), kelengasan tanah, kerapatan lindak, daya hantar hidrolik, dan kering tak balik ( irreversible). Tanah gambut mengandung asam-asam organik yang terdiri dari asam humat, asam fulfat dan asam humin kandungan asam-asam organik ini berhubungan erat dengan kecepatan mineralisasi yang terjadi pada tanah organik.

Pada umumnya $\mathrm{pH}$ tanah gambut berkisar antara 3-5 dan ada kecendrungan bahwa $\mathrm{pH}$ gambut daerah pantai lebih tinggi dibandingkan dengan $\mathrm{pH}$ gambut pedalaman (Setiadi, 1996). $\mathrm{pH}$ tanah 5,5-6,5 bisa dikatakan netral, bila $\mathrm{pH}$ lebih dari 6,5 akan menurukan ketersediaan unsur $\mathrm{P}, \mathrm{Mn}, \mathrm{Bo}$, dan $\mathrm{Zn}$ sedangkan tanah yang masam menyebabkan tanaman keracunan unsur $\mathrm{Fe}$ sebaliknya kahat akan unsur hara $\mathrm{N}, \mathrm{P}, \mathrm{Ca}$, $\mathrm{Mg}$, Bo, Cu, dan Mo.

Tanah gambut umumnya mempunyai nilai Kapasitas Tukar Kation (KTK) tinggi dibandingkan dengan tanah mineral. Kation adalah ion yang bermuatan positif seperti $\mathrm{Ca}{ }^{++}, \mathrm{Mg}^{++}, \mathrm{K}^{+}, \mathrm{Na}^{+}, \mathrm{NH}_{4}^{+}, \mathrm{H}^{+}, \mathrm{AL}^{+}$dan sebagainya. Nilai KTK memegang peranan penting dalam pengelolaan tanah dan dapat menjadi penciri kesuburan tanah. Di dalam tanah kation-kation tersebut larut dalam larutan tanah atau dijerap oleh koloid tanah. Banyaknya kation (dalam miliekuivalen) yang dapat dijerap oleh tanah per satuan berat tanah (biasanya per 100 gram) dinamakan kapasitas tukar kation (KTK) tanah. Dengan kata lain, KTK tanah adalah kemampuan tanah untuk menjerap dan menukarkan kationnya (Suwarno,2000).

Pada umumnya kandungan total nitrogen tanah gambut berkisar antara 2000 sampai $4000 \mathrm{~kg} / \mathrm{Ha}$ pada lapisan olah 0 sampai $30 \mathrm{~cm}$ namun yang tersedia bagi tanaman kurang dari 3\% dan selebihnya terdapat sebagai bahan organik komplek (Setiadi,1996).

\section{Mikroorganisme Lokal (MOL)}

Mikroorganisme Lokal (MOL) merupakan cairan yang terbuat dari bahan alami sebagai media tumbuh den berkembangnya mikroorganisme yang di mamfaatkan secara efektif untuk mempercepat dekoposisi atau penghancuran zat organik. Kandungan dalam zat ini berfungsi sebagai dekomposer sekaligus bioaktivator serta nutrisi tambahan bagi tanaman yang secara sengaja di kembangkan dari mikroorganisme di sekitar area tubuh tanaman. Bahan bahan ini di anggap memiliki kandungan zat perangsang tumbuh yang dapat sangat bermamfaat bagi tanaman.

Mikroorganisme tanah merupakan salah satu faktor utama yang memengaruhi kesuburan tanah sebagian besar pertumbuhan tanaman tidak terlepas dari peran mikroorganisme tanah. Untuk membuat larutan MOL di butuhkan 3 bahan utama :

\section{Karbohidrat}

spontan (lebih mudah di makan). Glukosa bisa di dapat dari gula pasir, gula merah, molase, air gula, air kelapa, nira dan lain lain.

\section{Sumber bakteri}


Bahan yang banyak mengandung mikroorganisme yang bermamfaat bagi tanaman antara lain buah-buahan, sayursayuran, keong mas, rebung bamboo, bonggol pisang, urine kelinci, pucuk labu, tapai singkong dan lain lain.biasanya dalam larutan MOL tidak hanya mengandung 1 mikroorganisme tetapi beberapa mikroorganisme di antaranya Rhizobium $s p$. Azospilium $s p$, pseudomonas $s p$, bacillus $s p$ dan bakteri pelarut fospat ( Lindung, 2015).

\subsubsection{Manfaat Mikroorganisme Lokal (MOL) \\ MOL (Mikroorganisme lokal)} merupakan salah satu cara memanfaatkan bahan lokal untuk dimanfaatkan menjadi pupuk sehingga tidak merusak lingkungan. Larutan MOL mengandung undur hara mikro dan makro dan juga mengandung bakteri yang berpotensi sebagai perombak bahan organik, perangsang pertumbuhan dan sebagai agen ppengendali hama dan penyakit tanaman.

MOL dapat digunakan sebagai pendekomposer, pupuk hayati dan sebagai pestisida organik terutama sebagai fungisida. Keunggulan dan kelebihan MOL antara lain:

- Mengandung bermacam-macam unsur organik dan mikroba yang bermanfaat bagi tanaman.

- Penggunaan MOL terbukti mampu memperbaiki kualitas tanah dan tanaman

- Tidak mengandung zat kimia berbahaya dan ramah lingkungan

- Mudah dibuat, bahan mudah didapatkan dan juga mudah dalam aplikasinya

- Sebagai salah satu upaya mengatasi pencemaran limbah

- Memperkaya keanekaragaman biota tanah.

\subsection{Kotoran Walet}

Di dalam kotoran walet terdapat kandungan nutrisi yang sangat tinggi juga baik bagi tanah, seperti nitroge, fosfor, kalium, kalsium, magnesium dan sulfur. Mamfaat burung walet dari segi pertanian juga sangat banyak. Karena $40 \%$ kotoran walet ini terbuat dari material organik murni sehingga sangat efektif untuk memperbaiki serta memperkaya nutrisi tanah.

Kotoran walet lebih aman ketimbang pupuk kimia, dikarenakan sering di gunakan untuk aktifator untuk pembuatan pupuk organik. Pada umumumnya menggunakan pupuk kotoran walet akan membuat tanaman tumbuh dengan batang yang lebih kuat dan pembentukan daun baru menjadi maksimal.

Kandungan nutrisi yang terdapat dalam kotoran walet sengat tinggi ketimbang kotoran ayam atau sapi. Karena kurangnya pengetahuan penggunaan kotoran walet sebagai pupuk, pertumbuhan tanaman sering di katakan gagal dalam pemakaian pupuk ini. Dalam penggunaannya untuk setiap tanaman terkadang takaran pupuk kotoran walet bisa berbeda untuk setiap jenis tanamannya, dan karena membutuhkan waktu untuk menentukan takaran yang tepat .

\subsubsection{Manfaat Kotoran Walet}

Kandungan nutrisi walet :

- Nitrogen

- Fosfor

- Kalium

- Magnesium

- Sulfur

Manfaat kotoran walet:

1. sebanyak $40 \%$ dari kotoran wallet terbentuk dari material organik uang efektif untuk memperbaiki serta memperkaya struktur dari tanah.

2. Kotoran wallet dapat berperan layaknya fungisida alami yang sangat berkhasiat bagi pertumbuhan tanaman karena mengandung berbagai bakteria dan mikrobiotik flora didalamnya.

3. Kandungan nutrisinya terbukti sangat cocok dijadikan pupuk bagi berbagai tanaman.

4. Kotoran wallet dapat mengontrol jumlah nematoda yang pada umumnya memberi efek negatif pada tanaman didalam tanah.

5. Kotoran wallet sering digunakan berbagai aktifator pada pembuatan pupuk organic atau kompos yang lebih aman dari pada pupuk kimia.

6. Kotoran walet yang dijadikan pupuk sangat ampuh dalam memebantu tanaman agar dapat menyerap unsur nutrisi yang baik bagi pertumbuhannya karena memiliki kapasitas tukar kation yang cukup tinggi.

7. Kotoran walet sangat kaya akan unsur makro dan mikro.

\section{METODOLOGI PENELITIAN}

\section{Waktu dan Tempat}

Penelitian ini telah dilaksanakan pada bulan Februari 2020 sampai juni 2020 yang bertempat di kampus UNISI Jalan Provinsi Parit 1 Tembilahan Hulu, Indragiri hilir, Riau. Analisis kandungan hara feses 
walet, tanah dan tanaman dilakukan di laboratorium Universitas Riau,

\subsection{Bahan dan Alat}

Bahan-bahan dalam percobaan ini adalah benih bawang merah varietas Bima, tanah gambut, pupuk kandang sapi, feses walet, gula merah dan air cucian beras. Sedangkan alat yang digunakan adalah polybag ukuran $10 \mathrm{Kg}$, cangkul, ember, gergaji, meteran dan alat tulis.

\subsection{Metode Penelitian}

Penelitian ini dilakukan dengan menggunakan Rancangan Acak Lengkap dengan faktor tunggal menggunakan 6 perlakuan MOL dan diulang sebanyak 3 kali ulangan sehingga terdapat 18 unit percobaan. Setiap unit percobaan terdiri dari 3 polybag tanaman. 2 polybag tanaman di jadikan tanaman sampel untuk menghitung tinggi tanaman, jumlah umbi per rumpun, berat umbi basah per rumpun, berat umbi kering per rumpun, berat umbi layak jual. Satu (1) polybag polybag tanaman yang sudah di tandai dengan spidol merah di gunakan untuk menghitung berat berangkasan kering tanaman. Untuk menghitung kemampuan berbunga di hitung dengan semua polybag dalam satu unit perlakuan. Perlakuan terdiri dari :

Konsentrasi perlakuan yang digunakan dalam penelitian ini adalah : $\mathrm{AO}=0 \% \longrightarrow 0 \mathrm{ml} \mathrm{MOL}+2100 \mathrm{ml}$ air $\mathrm{A} 1=5 \% \longrightarrow 105 \mathrm{ml} \mathrm{MOL}+1995 \mathrm{ml}$ air $\mathrm{A} 2=10 \% \longrightarrow 210 \mathrm{ml} \mathrm{MOL}+1890 \mathrm{ml}$ air $\mathrm{A} 3=15 \% \rightarrow 315 \mathrm{ml} \mathrm{MOL}+1785 \mathrm{ml}$ air $\mathrm{A} 4=20 \% \rightarrow 420 \mathrm{ml} \mathrm{MOL}+1680 \mathrm{ml}$ air $\mathrm{A} 5=25 \% \rightarrow 525 \mathrm{ml} \mathrm{MOL}+1575 \mathrm{ml}$ air Dasar rancangan penelitian ini berdasarkan penelitian Yeremia (2016) dengan judul konsentrasi rebung bambu terhadap pertumbuhan tanaman sawi caisim. Dalam hasil penelitiannya bahwa perlakuan pada konsentrasi $5 \%$ berpengaruh nyata terhadap pertumbuhan tanaman sawi caisim di bandingkan dengan perlakuan 10 $\%$ dan $15 \%$.

Dalam penelitian ini semua data dikumpulkan kemudian dianalisisi secara statistik dengan analisis of varians (anova). Model analisis yang digunakan adalah: Model Linier Rancangan Acak Lengkap (RAL)

Yij $\quad=\mu+T i+\Sigma i j$

Dimana :

Yij = nilai pengamatan dari perlakuan ke-i dan ulangan ke-j

$\mu=$ nilai tengah umum

$\mathrm{Ti}=$ pengaruh perlakuan ke-i
$\Sigma \mathrm{ij}=$ pengaruh galat percobaan dari perlakuan ke-i dan ulangan ke-j

Data yang diperoleh dianalisis secara statistik menggunakan analisis sidik ragam (uji F) dan dilanjutkan dengan Uji Kontras. Penempatan masing-masing perlakuan dilakukan secara acak di sajikan pada Lampiran 3.

\subsection{Pelaksanaan Penelitian}

Adapun rincian kegiatan dalam penelitian ini dapat diuraikan dengan beberapa kegiatan diantara nya sebagai berikut :

\subsubsection{Pembuatan
Mikroorganisme lokal (MOL)}

Larutan

Prosedur dan tata cara Larutan Mikroorganisme lokal (MOL) dapat dilihat pada lampiran 4.

\subsubsection{Persiapan Lahan dan Pemasangan Rumah Plastik}

Tanah diambil secara bulk composite pada kedalaman $20 \mathrm{~cm}$, kemudian dibersihkan dari akar dan kotoran yang ada. Tanah di campur dengan pupuk kandang sapi dengan perbandingan $3: 1$ (6 kg tanah dan $2 \mathrm{~kg}$ pupuk kandang sapi) lalu dikeringanginkan terlindung dari sinar matahari sampai kondisi lembab kemudian ditimbang sebanyak $8 \mathrm{~kg}$ dan memasukkannya ke dalam masing-masing polybag.

Pembuatan rumah pelastik di buat secara sederhana. Rumah plastik di buat dengan menghadap ke timur, dinding rumah plastik di buat setinggi $15 \mathrm{~cm}$ dari permukaan tanah, atap rumah pelastik dibuat dengan tinggi 1 Meter dari permukaan tanah, atap yang menghadap ke timur lebih tinggi $10 \mathrm{~cm}$ dari atap yang menghadap ke barat.

\subsubsection{Analisis tanah awal dan Feses} Walet

Analisis tanah awal sebelum inkubas meliputi : analisis $\mathrm{pH}$ yang diukur dengan $\mathrm{pH}$ meter, N-total dengan metode kjeldah, Ptersedia dengan metode Bray I, K, Ca dan $\mathrm{Mg}$ dengan metode pencucian ammonium asetat $\left(\mathrm{NH}_{4} \mathrm{COOH}\right)$ dalam larutan ber-pH 5 .

Feses walet dianalisis terlebih dahulu $\mathrm{pH}$ dan kandungan hara $\mathrm{N}, \mathrm{P}, \mathrm{K}, \mathrm{Ca}, \mathrm{Mg}$ dilaboratorium sehingga dapat diketahui jumlah unsur hara yang disumbangkan pada MOL dari feses walet dalam memenuhi kebutuhan unsur hara tanaman.

\subsubsection{Penanaman}

Penanaman dilakukan dengan melakukan pembersihan kulit umbi yang paling luar yang telah mengering, kemudian umbi dipotong $1 / 3$ bagian secara melintang pada ujung umbi, tujuan dilakukannya 
pemotongan umbi yaitu untuk penghentian masa dormansi pada umbi tersebut sehingga mempercepat proses pertunasan. Setelah itu, umbi direndam dengan air selama \pm 15 menit, lalu ditanam ke dalam wadah semai berupa polibeg yang telah disediakan, dan dalam 1 polibeg terdapat 1 umbi bawang merah yang merupakan bahan tanaman, umbi ditutup $3 / 4$ bagian dengan menggunakan tanah halus, Penanaman sebaiknya dilakukan pada sore hari agar umbi bawang merah yang di tanam tidak langsung kering.

\subsubsection{Pemberian Label}

Pemasangan label dapat di lakukan sebelum tanam guna untuk mempermudah dan menandai perlakuan tiap polybag sesuai dengan lay out.

\subsubsection{Pemeliharaan}

Pemeliharan tanaman bawang merah meliputi :

\section{Penyiraman}

Penyiraman dilakukan dengan menggunakan hand sprayer dengan sistem penyiraman pada daun dan pada lubang tanam. Waktu penyiraman pada pagi hari jam $07.00 \mathrm{~s} / \mathrm{d} 10.00$ WIB dan pada sore hari jam 16.00 s/d 18.00 WIB. Jika turun hujan, maka tidak perlu dilakukan penyiraman.

\section{Penyulaman}

Penyulaman dilakukan pada bibit bawang merah yang pertumbuhannya jelek, atau mati. Waktu penyulamannya dilakukan sampai berumur 2 minggu setelah tanam.

\section{Pemupukan}

Pemupukan dengan MOL feses walet dilakukan pada umur 1 minggu setelah tanam (MST) sampai umur 6MST, dengan interval waktu pemupukan 1 minggu sekali. Cara pemupukan dengan menyiramkannya ke tanah pada polybag. Pemupukan dilakukan pada sore hari. Konsentrasi pemupukan disesuaikan dengan perlakuan.

\section{Panen}

Bawang merah dapat dipanen setelah umurnya cukup tua, biasanya pada umur 60-70 hari. Tanaman bawang merah dipanen setelah terlihat tanda-tanda berupa leher batang $60 \%$ lunak, tanaman rebah dan daun menguning. Pemanenan sebaiknya dilaksanakan pada keadaan tanah kering dan cuaca yang cerah untuk mencegah serangan penyakit busuk umbi di gudang (Sumarni \& Hidayat 2005).

Bawang merah yang telah dipanen kemudian diikat pada batangnya untuk mempermudah penanganan. Selanjutnya umbi dijemur sampai cukup kering (1-2 minggu) dengan menggunakan sinar matahari langsung, diikuti dengan pengelompokan berdasarkan kualitas umbi.

\subsection{Parameter Yang Diamati}

Parameter yang di amati pada penelitian ini adalah :

\subsubsection{Tinggi Tanaman $(\mathrm{cm})$}

Tinggi tanaman diukur mulai dari pangkal sampai ke ujung daun terpanjang. Tinggi tanaman diukur pada saat akhir vegetatif tanaman.

\subsubsection{Jumlah Umbi per Rumpun Tanaman (umbi) \\ Umbi yang dihitung adalah umbi} yang telah tumbuh sempurna dengan kriteria keras atau padat dan bewarna merah mengkilap. Pengamatan dilakukan pada saaat panen.

\subsubsection{Berat Umbi per Rumpun Tanaman (g)}

Berat umbi per rumpun dihitung pada serumpun bawang merah per polybag. Umbi yang di hitung adalah umbi yang telah tumbu sempurna dengan kriteria keras atau padat dan bewarna merah mengkilat. Pengamatan jumlah umbi dilakukan pada saat panen.

\subsubsection{Berat Kering Umbi per Rumpun}

(g)

Bobot umbi kering diperoleh dengan melakukan penimbangan tanaman yang telah di kering anginkan selama 3-7 hari. Pengamatan dilakukan setelah panen.

\subsubsection{Bobot Umbi Layak Jual}

Bobot umbi layak jual dan tidak layak jual (g) dilakukan seleksi umbi yaitu memisahkan umbi yang normal dan rusak. Ketentuan bobot umbi yang rusak (tidak layak jual) yaitu bewarna pucat, bentuk umbi yang tidak bulat dan kurang dari $4 \mathrm{~g}$ (Mawardi,2014).

\section{HASIL DAN PEMBAHASAN}

\subsection{Hasil Analisis Tanah Awal}

Hasil analisis tanah awal pada lahan penelitian yang dilaksanakan di Kampus II Unisi Fakultas Pertanian Jl. Lintas Propinsi Parit 01, Kelurahan Tembilahan Hulu, Kecamatan Tembilahan Hulu, Kabupaten Indragiri Hilir Propinsi Riau dapat dilihat pada Tabel 1.

Tabel 1. Analisis Kandungan Hara Tanah Gambut Kebun Percobaan Fakultas Pertanian Universitas Islam Indragiri Tembilahan 


\begin{tabular}{|l|l|l|l|l|}
\hline $\begin{array}{l}\mathrm{N} \\
\mathrm{o}\end{array}$ & $\begin{array}{l}\text { Jenis } \\
\text { Analisis }\end{array}$ & Tanah & Satuan & $\begin{array}{l}\text { Kriteri } \\
\mathrm{a}\end{array}$ \\
\hline 1 & $\mathrm{pH}$ & 5,25 & & agak \\
2 & $\mathrm{~N}$ total & 0,49 & $\%$ & masa \\
3 & $\mathrm{P}$ & 31 & $\mathrm{ppm}$ & $\mathrm{m}$ \\
4 & $\mathrm{~K}$ & 0,78 & $\mathrm{Me} / 10$ & Tinggi \\
5 & $\mathrm{Ca}$ & 1,65 & $0 \mathrm{~g}$ & Tinggi \\
& & & $\mathrm{Me} / 10$ & Sedan \\
& & & $\mathrm{g}$ & $\mathrm{g}$ \\
\hline
\end{tabular}

Sumber:Kementrian Pendidikan dan Kebudayaan Fakultas Pertanian Universitas Riau Laboratorium Ilmu Tanah

Dari hasil analisis tanah awal terlihat bahwa $\mathrm{pH}$ tanah gambut yang digunakan dalam penelitian ini termasuk kriteria $\mathrm{pH}$ rendah yang mengindikasikan reaksi tanah masam. Tanah yang masam adalah tanah dengan kandungan ion hydrogen $\left(\mathrm{H}^{+}\right)$yang tinggi. Menurut Jones (1984), nilai pH rendah itu disebabkan oleh asam-asam organik dan ion hidrogen dapat ditukar $(\mathrm{H}-$ dd) yang tinggi terkandung dalam tanah gambut. Prasetyo (1996) menambahkan bahwa tingginya asam-asam organik disebabkan oleh dekomposisi bahan organik terutama dalam keadaan anaerob yang akan menghasilkan asam - asam organik yang tinggi. Asam-asam organik akan mengalami disosiasi $\mathrm{H}$ dari gugus fungsional baik gugus karboksil $(-\mathrm{COOH})$ maupun fenol $(-\mathrm{OH})$.

Kandungan N $(0,49 \%)$, tinggi, tetapi bukan berarti kebutuhan $\mathrm{N}$ tanaman tercukupi, sebagian besar $\mathrm{N}$ berada dalam bentuk organik seperti yang diyatakan Driessen (1977) dalam Setiadi (1996) bahwa gambut, $\mathrm{N}$ tersedia kurang dari 3,\% dan selebihnya terdapat dalam bentuk bahan organik yang kompleks sehingga memerlukan proses mineralisasi untuk dapat digunakan tanaman.

Ketersedian P (3092.72 ppm) pada tanah gambut tergolong sedang. Penghancuran bahan organik. Menurut Hardjowigeno (2003) akan membebaskan sejumlah N, P dan $\mathrm{S}$ dalam bentuk tersedia bagi tanaman. Pada umumnya tanah gambut menurut Black (1968) dalam Setiadi (1996) Sebagian besar $P$ terdapat dalam senyawa $P$ anorganik dimana $P$ anorganik lebih berkorelasi dengan kebutuhan tanaman. Kandungan $\mathrm{K}(0,78 \mathrm{Cmol} / \mathrm{kg})$ tergolong tinggi hanya saja unsur $\mathrm{K}$ masih terjerap dalam jaringan tanaman yang membentuk tanah gambut.

\subsection{Tinggi Tanaman}

Hasil analisis sidik ragam (lampiran 3a) menunjukkan bahwa pemberian konsentrasi MOL feses walet berpengaruh nyata terhadap tinggi tanaman bawang merah (Allium cepa L.) Varietas Bima di media gambut. Hasil uji lanjut dengan HSD pada tahap $5 \%$ dapat dilihat pada grafik dibawah ini

Grafik 2. Pengaruh Pemberian Konsentrasi (MOL) dari Feses Walet terhadap Tinggi Tanaman Bawang Merah (Allium cepa L) pada Media Gambut

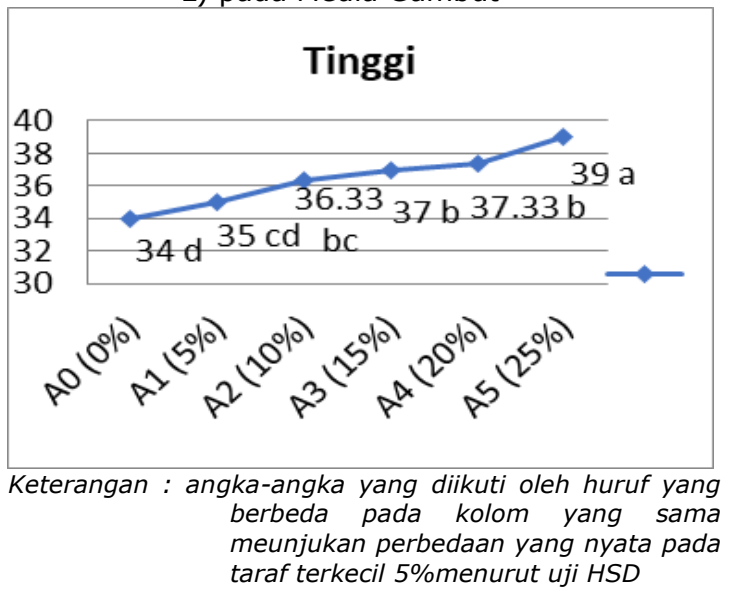

Grafik 2 menunjukan bahwa tinggi tanaman tertinggi ada pada perlakuan A5 yaitu pada konsentrasi MOL feses walet $25 \%$ yaitu 39,00 cm. Hal ini disebabkan konsentrasi MOL yang diberikan cukup tinggi sehingga mempercepat proses dekomposisi bahan organik di dalam tanah sehingga materi yang diuraikan dapat diserap oleh tanaman yang hidup di sekitar daerah tersebut. Proses dekomposisi bahan organik umumnya mempunyai kemampuan yang lebih baik dibanding bakteri dalam mengurai sisa-sisa tanaman. Tinggi tanaman bawang merah pada penelitian ini rata-rata mencapai 34-39 cm dan sudah sesuai dengan deskripsi tanaman bawang merah Varietas Bima. Keadaan tersebut terjadi karena unsur hara $\mathrm{N}$ dapat di serap oleh tanaman secara optimal. Unsur hara $\mathrm{N}$ dibutuhkan tanaman dalam jumlah yang besar agar pertumbuhan dan perkembangan. Unsur hara N merupakan anasir penting dalam pembentukan klorofil, protoplasma, protein dan asam asam nukleat. Unsur N, P, K, memberikan respon positif terhadap pertumbuhan bawang merah, selain itu kandungan $\mathrm{N}, \mathrm{P}, \mathrm{K}$, berperan penting dalam proses asimilasi pada tanaman dan meningkatkan produksi tanaman

$$
\text { Hasnadi dan Saleh }
$$
menyatakan bahwa bahan organik dapat memperbaiki sifat fisika tanah, menggiatkan mikroorganisme, meningkatkan jumlah air dan memberikan pertumbuhan akar tanaman menjadi lebih baik. Menurut Hakim et al (1986) bahan organik adalah bahan pemantapan agregat tanah yang merupakan sumber hara tanaman, sumber energi dari 
sebagian besar organisme tanah, sehingga menyebabkan perkembangan akar menjadi lebih baik dan dapat meningkatkan absorsi unsur hara terutama Nitrogen oleh akar. Menurut Sutejo dan Kartasapoetra (1998) bahwa pertumbuhan vegetatif tanaman diperlukan unsur hara $\mathrm{N}$ yang merupakan bagian dari protoplasma dan inti sel. Sebagai bagian dari inti sel, unsur tersebut sangat penting dalam pembelahan sel dan perkembangan jaringan jaringan meristem. $\mathrm{Hal}$ ini sesuai dengan pendapat Rostikawati (2012) yang menyatakan bahwa dengan pemberian cairan MOL akan meningkatkan kandungan mikroba di dalam tanah sehingga akan mempercepat proses mineralisasi sehingga dapat berjalan secara optimal keadaan tersebut akan meningakatkan kebutuhan unsur hara pada tanaman menjadi terpenuhi dengan baik. Hal ini didukung oleh pendapat Panudju (2011) yang menyatakan bahwa MOL berfungsi sebagai bahan

utama dalam proses pengomposan bahan organik menjadi kompos.

\subsection{Jumlah Umbi per Rumpun \\ (siung)}

Hasil analisis sidik ragam (lampiran 5b) menunjukan bahwa pemberian konsentrasi (MOL) dari feses walet berpengaruh nyata terhadap jumlah umbi per rumpun tanaman bawang merah (Allium cepa L.). Hasil uji lanjut dengan HSD pada tahap $5 \%$ dapat dilihat pada grafik dibawah ini

Grafik 3 . Pengaruh Pemberian Konsentrasi (MOL) dari Feses Walet terhadap Jumlah Umbi Perrumpun Bawang Merah (Allium cepa L) pada Media Gambut.

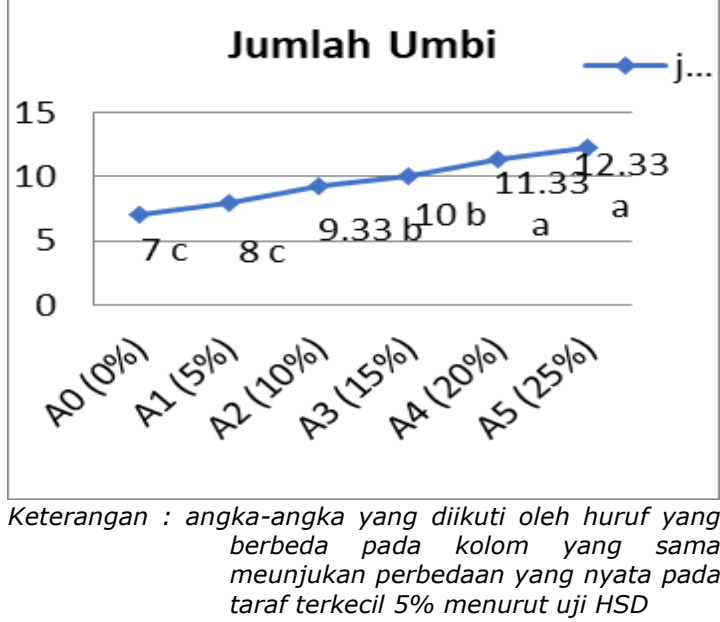

Grafik 3 menunjukkan bahwa jumlah umbi terbanyak ada pada perlakuan A5 pada konsentrasi MOL feses walet $25 \%$ yaitu 12,33 siung, hal ini berhubungan langsung dengn ketersediaan unsur hara dalam tanah yang mempengaruhi pertumbuhan tanaman. Posfor merupkan unsur hara makro esensial yang memegang peranan penting dalam pemeran penting dalam berbagai peoses seperti fotosintesis, asimilasi dan respirasi. Fospor merupakan komponen struktural dari sejumlah molekul pentransfer energi ADP, ATP, NAD, NADH. Serta senyawa sistem informasi genetik DNA dan RNA (Gardner et al 1985). Emleton et al (1973) menyatakan bahwa $P$ berperan dalam pertumbuhan tanaman. Fosfat di butuhkan oleh tanaman untuk pembentukan sel pada jaringan akar dan tunas yang sedang tumbuh serta meperkuat batang.

Penambahan unsur hara yang dibutuhkan oleh tanaman dapat meningkatkan pertumbuhan dan perkembangan tanaman terutama untuk pembentukan umbi. Menurut Suryana (2008), suatu tanaman akan tumbuh dan berkembang dengan subur apabila unsur hara yang diberikan dapat diserap oleh suatu tanaman dan dalam bentuk yang sesuai untuk diserap akar serta dalam keadaan yang cukup. Selain itu Menurut Gough (2002), jumlah daun yang terbentuk selama pertumbuhan vegetatif sangat mempengaruhi jumlah umbi.

Pupuk fosfor merupakan komponen penyusun senyawa untuk transfer energi (ADP dan ATP). Pupuk $P$ berfungsi dalam pembentukkan akar akan meningkatkan penyerapan unsur penyerapan unsur hara $\mathrm{N}$, $P$, dan $K$ dan unsur hara lainnya. Soepardi (1983) menyatakan bahwa unsur $P$ meningkatkan pembentukan bulubulu akar sehingga memperluas bidang serapan dan mendukung penyerapan hara makro dan mikro yang dimanfaatkan untuk pertumbuhan.

\subsection{Berat Basah Umbi per Rumpun Tanaman (g)}

Hasil analisis sidik ragam (lampiran 5c) menunjukkan bahwa pemberian konsentrasi (MOL) dari feses walet berpengaruh nyata terhadap berat umbi perumpun tanaman bawang merah (Allium cepa L.). Hasil uji lanjut dengan HSD pada tahap 5\% dapat dilihat pada grafik dibawah ini

Grafik 4 menunjukan bahwa berat umbi per rumpun terberat ada pada perlakuan A5 pada konsentrasi MOL feses walet $25 \%$ yaitu 37,33 gram, hal ini dikarenakan kandungan unsur $\mathrm{K}$ yang ada dalam feses walet dapat memberikan pengaruh dalam pembentukan umbi dimana unsur $\mathrm{K}$ berperan secara umum untuk pembentukan umbi dan dapat meningkatkan 
aktifitas fotosintesis dan kandungan klorofil daun sehingga dapat meningkatkan bobot basah dan bobot kering tanaman

Grafik 4 . Pengaruh Pemberian Konsentrasi (MOL) dari Feses Walet terhadap Berat Basah Umbi perrumpun Bawang Merah (Allium cepa L) pada Media Gambut.

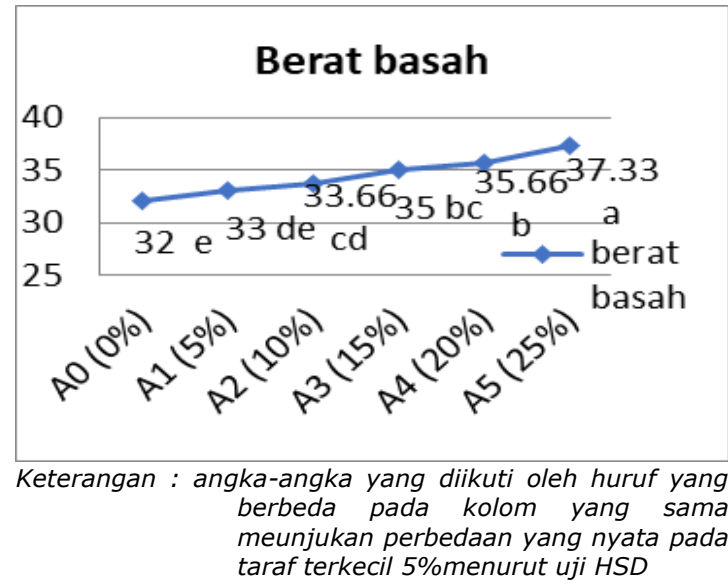

Hal ini sesuai dengan pernyataan Napitupulu dan Winarto (2009) yang menyatakan bahwa kalium berperan dalam meningkatkan pertumbuhan vegetatif tanaman seperti pembentukan, pembesaran dan pemanjangan umbi serta berpengaruh dalam meningkatkan bobot bawang merah. Selain itu di dukung oleh Damanik dkk (2010) yang menyatakan bahwa kalium sangat dibutuhkan untuk proses pembentukan fotosintesis serta dapat meningkatkan berat umbi. Hal ini didukung juga oleh pernyataan Indriani (1998) yang menyatakan bahwa kalium penting bagi pertumbuhan tanaman, antara lain untuk mempertinggi tanaman dan memperbaiki produksi dari umbi.

\subsection{Berat Kering Umbi per Rumpun} dan umbi layak jual (g)

Hasil analisis sidik ragam (lampiran 5d) menunjukkan bahwa pemberian konsentrasi MOL dari feses walet berpengaruh nyata terhadap berat kering umbi perumpun dan umbi layak jual tanaman bawang merah (Allium cepa L.). Hasil uji lanjut dengan HSD pada tahap $5 \%$ dapat dilihat pada grafik dibawah ini

Grafik 5 . Pengaruh Pemberian Konsentrasi (MOL) dari Feses Walet terhadap Kerat Kering Umbi perrumpun Bawang Merah (Allium cepa L) pada Media Gambut.

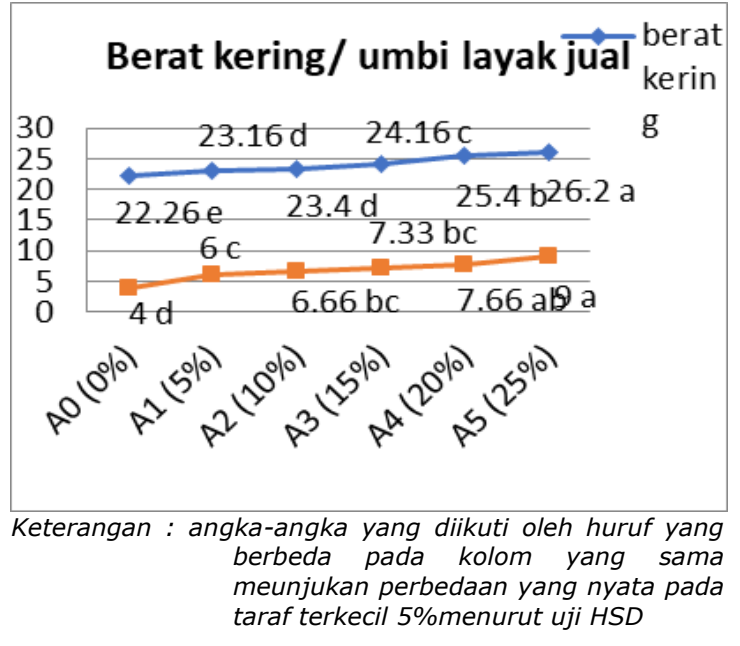

Grafik 5 menunjukan bahwa berat kering umbi per rumpun terberat ada pada perlakuan A5 pada konsentrasi MOL feses walet $25 \%$ yaitu 26,20 gram, hal ini dikarenakan MOL feses walet mempunyai kandungan $\mathrm{N}$ yang cukup sehingga asupan unsur $\mathrm{N}$ yang digunakan oleh tanaman bawang merah untuk pembentukan atau pertumbuhan bagian vegetatif seperti daun, batang dan akar yang berdampak pada bobot biomasa tanaman, selain itu juga berperan pula dalam proses fotosintesis dimana potosintat hasil fotosintesis akan meningkatkan bobot kering tanaman, selain itu bobot kering mencerminkan baik tidak nya pertumbuhan suatu tanaman merupakan akumulasi hasil fotosintat berupa protein, karbohidrat dan lipid yang disimpan pada batang, buah, umbi atau polong

Menurut Supriyatna, et al, (2016), hasil analisis rata-rata bobot kering tanaman bawang merah dengan kombinasi kompos menunjukan hasil yang berbeda nyata disebabkan karena pembentukan umbi bawang merah berasal dari pembesaran lapisan -lapisan batang semu yang kemudian berkembang menjadi umbi bawang merah. Kandungan $\mathrm{K}$ yang tinggi menyebabkan $\mathrm{K}+$ yang mengikat air dalam tubuh tanaman akan mempercepat proses potosintesis. Hasil potosintesis inilah yang merangsang pembentukan umbi menjadi lebih besar sehingga dapat meningkatkan bobot kering tanaman.

Menurut Asgar dan Sinaga (1992) pengeringan umbi bawang merah yang dilakukan dengan cara dikering anginkan menyebabkan kehilangan kadar air yang cukup signifikan sehingga menyebabkan susutnya bobot umbi. Pengeringan merupakan perpindahan panas dan massa secara transien serta beberapa laju proses seperti transformasi fisika atau kimia, yang 
pada gilirannya dapat menyebabkan perubahan mutu hasil. Prinsip pengeringan adalah terjadinya penguapan air dari bahan atau material ke udara karena perbedaan kandungan air antara udara dengan bahan yang dikeringkan (Mujumdar, 2001).

Grafik 5 menunjukan bahwa umbi layak jual yang terbaik ada pada perlakuan A5 yaitu 9,00, ukuran umbi yang kecil merupakan indikasi bahwa kandungan senyawa organik dalam umbi seperti karbohidrat, protein, lemak dan lain-lain sangat sedikit, sehingga komponen umbi layak jual yang diperoleh juga relatif sama dan sedikit. Umbi yang memiliki diameter besar dan sedang lebih sesuai permintaan pasar sebagai umbi untuk konsumsi, sedangkan umbi dengan diameter kecil lebih baik digunakan sebagai umbi benih.

Hasil penelitian Putrasamedja (2007) menunjukkan bahwa benih yang berukuran kecil mampu membentuk ukuran umbi yang lebih besar, sehingga dalam penampilannya menurut ukuran lebih baik dibandingkan dengan umbi-umbi yang berasal dari penanaman umbi berukuran besar. Diameter umbi yang berbeda pada ketiga varietas tersebut juga dipengaruhi oleh faktor genetik masing-masing varietas. Menurut Putrasamedja dan Soedomo (2007), selain lingkungan, besar umbi juga dipengaruhi oleh faktor genetik. Jika berbagai varietas ditanam di lahan yang sama, maka besar umbi tiap varietas juga berbeda.

Menurut Basuki (2009) karakteristik bawang yang disukai petani adalah umbi berbentuk bulat, besar dengan diameter lebih dari $2 \mathrm{~cm}$ dan berwarna merah tua. Bentuk umbi yang kecil sangat terpengaruh pada saat perkembangannya, terutama pada energi yang dibutuhkan saat pengisian sel. Sel-sel umbi lapis mengandung vakuolavakuola yang berisi minyak atsiri (Fahn, 1992).

Minyak atsiri adalah hasil metabolitsekunder yang termasuk dalam senyawa aromatik. Akibat dari persaingan dalam memperoleh energi tersebut maka metabolisme senyawa tersebut terhambat, sehingga yang disimpan dalam sel-sel pangkal daun hanya sedikit, walaupun berlapislapis tetapi secara relatif belum dapat menambah diameter umbi secara nyata (Robinson, 1995). Beukema (1979) dalam Ruminto dan Sugandi (1988) menyatakan bahwa pembesaran umbi lapis diakibatkan oleh pembesaran sel yang lebih dominan dari pada pembelahan sel. Peningkatan berat basah umbi dipengaruhi oleh banyaknya absorbsi air dan penimbunan hasil fotosintesis pada daun untuk ditranslokasikan bagi pembentukan umbi.

4.1 .

\section{KESIMPULAN DAN SARAN}

\subsection{Kesimpulan}

1. Pemberian MOL feses walet memberikan pengaruh nyata, terhadap parameter yang diamati yaitu tinggi tanaman, berat basah umbi, berat kering umbi, jumlah umbi layak jual dan jumlah umbi per rumpun

2. Konsentrasi $25 \%$ MOL feses walet merupakan dosis yang terbaik untuk pertumbuhan dan produksi tanaman bawang merah pada media gambut

\subsection{Saran}

Perlu dilakukan penelitian lanjutan dengan menggunakan pupuk yang sama untuk mengetahui produktivitas umbi bawang merah yang berasal dari varietas yang berbeda ditanah gambut

\section{DAFTAR PUSTAKA}

[1] AAK, 2004. Pedoman Bertanam Bawang Merah, Kanisius, Yogyakarta.

[2] Agustina, L. 2004. Dasar Nutrisi Tanaman. Rineka Cipta, Jakarta.

[3] Asgar, A, dan R.M. Sinaga. 1992. Pengeringan Bawang Merah (Allium ascalonicum L.) dengan Menggunakan Ruangan Berpembangkit Vorteks. J.Hort .12:48-55.

[4] Azmi C. IM Hidayat. G Wiguna. 2011. Pengaruh varietas dan ukuran umbi terhadap produktiftitas bawang merah. Hort. 21 (3):206-213.

[5] Badan Pusat Statistik. 2016. Produksi Bawang Merah Menurut Provinsi Tahun2015. Kementrian Pertanian Republik Indonesia, Riau.

[6] Badan Pusat Statistik. 2019. Produksi Bawang Merah Menurut Provinsi Tahun 2015. Kementrian Pertanian Republik Indonesia, Riau.

[7] Badan Standarisasi Nasional. 2004. Standar Kualitas Kompos. SNI 19-70302004

[8] Basuki, R.S., 2009. Analisa kelayakan teknis dan ekonomis teknologi budidaya bawang merah dengan biji botani dan benih umbi tradisional. J. Hort. 19(2):21-27.

[9] Buckman, H dan N.C Brady. 1982. Kesuburan Tanah dan Pemupukan Tanah Pertanian. Pustaka Buana. Bandung. 
[10] Darmawan, J. dan J. Baharsyah. 1983. Dasar-dasar Fisiologi Tanaman. Institut Pertanian Bogor, Bogor.

[11] Dewantoro. 2012. Petani Minta Impor Bawang Merah Tepat Sasaran. (Diakses pada kamis, 24 oktober 2019).

[12] Dewi`, Nurfita. 2012. Untung Segunung Bertanam Aneka Bawang. Pustaka Baru Press, Yogyakarta.

[13] Djunaedy A. 2009. Pengaruh jenis dan dosis pupuk bokashi terhadap pertumbuhan dan hasil kacang panjang (Vigna sinensis L.). Agrovigor. 2 1: 4246.

[14]Fahn, A. 1992. Anatomi Tumbuhan . PT Gramedia Jakarta

[15] Firmansyah, I. dan N. Sumarni. 2013. Pengaruh Dosis Pupuk $\mathrm{N}$ dan Varietas Terhadap pH Tanah, N-Total Tanah, Serapan N, dan Hasil Umbi Bawang Merah (Allium ascalonicum L.)

[16] Hadisuwito, S. 2012. Membuat Pupuk Organik Cair. Agromedia Pustaka, Jakarta.

[17] Hardjowigeno, S. 1997. Ilmu Tanah. Akademi Pressindo. Jakarta. Universitas Gajahmada, Yogyakarta.

[18] Harjono. 2000. Kunci Bercocok Tanam Tanaman Bayam Merah. Sinar Baru. Bandung.

[19] Iteu M, Hidayat, Putrasameja S, Azmin C, Laporan kegiatan 1804.17.A3, 2011. Persiapan pelepasan varietas bawang merah umbi dan TSS.

[20] Mujumdar, A.S. 2001. Panduan Praktis Mujumdar untuk Pengeringan Industrial. Sakamon Devahastian (Ed.). Alih Bahasa: Armansyah H. Tambunan. IPB Press. Bogor, Indonesia. 223 hal.

[21] Napitupulu, D. dan L. Winarto, 2010. Pengaruh Pemberian dan Konsentrasi Pupuk $\mathrm{N}$ dan $\mathrm{K}$ Terhadap Pertumbuhan dan Produksi Bawang Merah, J. Hotr. 20 (1):27-35 